Article

\title{
Risk Assessment of Ex-Post Transaction Cost in Construction Projects Using Structural Equation Modeling
}

\author{
Zaigham Ali ${ }^{1,2, * \mathbb{C}}$, Fangwei Zhu ${ }^{1, *}$ and Shahid Hussain ${ }^{1}$ \\ 1 Faculty of Management and Economics, Dalian University of Technology, Dalian 116024, China; \\ shahidkhoja@mail.dlut.edu.cn \\ 2 Department of Business Management, Karakoram International University, Gilgit-Baltistan 15100, Pakistan \\ * Correspondence: zaigham.ali@kiu.edu.pk (Z.A.); zhufw@dlut.edu.cn (F.Z.)
}

Received: 24 September 2018; Accepted: 30 October 2018; Published: 2 November 2018

check for updates

\begin{abstract}
The transaction cost (TC) escalation is the pervasive problem in the construction industry, which is continuously a threat to maintaining the life cycle cost of projects. Researchers have described the reality of risk for economic transactions. This study has taken the risk as a phenomenon to explore its influence on ex-post TC in construction projects. A questionnaire survey was undertaken from industry professionals to assess the risk of ex-post TC escalation in public-sector construction projects. In total, 475 surveys were conducted in Pakistan and used in the analysis. The data were analyzed using structural equation modeling (SEM) and the measurement and structural model was validated to determine the influence of risk on ex-post TC. The final SEM results show that internal and external risk, including sub hypothesized risks, positively influence TC. The weight of relative importance shows technical risk (23.82\%) and environmental risk (22.88\%) as significant sub-contributors from internal and external sources, respectively. This study recommends substantial investment in human capacity development to reduce the deficiencies in the ex-ante phase of the projects that help to reduce the risk of ex-post TC escalation. It also suggests the adoption of strict policies on contingency claims, and recommends nontraditional ways of monitoring to overcome the risk of ex-post TC. This study's results provide valuable information for industry professionals and practitioners to maintain life cycle costs as a contribution to sustainable construction.
\end{abstract}

Keywords: risk; ex-post transaction cost; construction projects; contracting; contractor

\section{Introduction}

Risk mitigation strategies in project planning determine project performance. The project management literature has classified various risks that influence project performance [1]. However, this study explores the cost risk of construction projects. The cost risk means the risk of transaction cost (TC) escalation, which enhances the total project cost. Drawing on transaction cost economics (TCE) theory, this study posits that the owner during project operation incurs not only production cost, but also TC. It is due to the owner's limited rationality to make flawless contracts; consequently, various risks emerge, which require periodic cost adjustments. TCE theory also discusses the opportunistic behavior of contractors who work for their interest cause to increase the risk of TC escalation. Moreover, the risk of TC is also escalated due to uncertainties in the project environment [2]. However, studies found that risks of TC originating from the owner are due to design errors and omissions [3], work acceleration [4], unrealistic project estimation, and change of project schedule [5], etc. Resultantly, the contractor haggles over the claims. Likewise, TC escalation could be the result of risks associated with various external sources on which both trading partners have little or no control over, such as 
political instability, hyperinflation, and other unforeseen conditions [5,6]. Thus, risk assessment of TC escalation is under the attention of such anomalies, which are continuously a challenge for practitioners to keep the project cost constant till project completion. The intuition behind the pervasive phenomenon of TC escalation, especially in developing countries, is due to a knowledge deficiency on risk, weak institutional governance, and environmental uncertainty [7]. However, adequate consideration of these risks at the outset of contracting increase the probability of reducing TC escalation problems during project operations. Generally, the production cost is a public expenditure. On the contrary, TC is a hidden cost [8], and the identification of associated risk is practically challenging and largely ignored in previous studies. In the literature, TCs are classified into two categories: Ex-ante TC and ex-post TC. In both phases, it is the risk which causes escalation of TC. While mitigating risk, it is suggested that the elimination of all risks would be unrealistic, even claiming to consider all of them would be a failure. The pragmatic approach is to identify the critical risk factors and make a strategy for control [9]. In similar lines, this study focuses on the essential risks in the ex-post phase of construction projects.

Researchers have applied TC perspectives in various construction-related topics. For instance, the initial application was to determine the appropriate governance structure in organizations [10]. Later on, it was applied for contracting and sub-contracting [11,12], and measuring TC in projects [13,14]. Li et al. [15] and Guo et al. [16] applied the TCE framework and found that it enhances management efficiency and reduces uncertainty in a transaction environment. However, most of the construction literature discusses structural methodologies and systematic studies on general risk and its influence on the total project cost [17-19]. Karimi Azari et al. [9] suggested identifying the risk before it becomes a problem. Despite the importance of risk, studies have not adequately acknowledged the role of risk that escalates TC, due to which it becomes a substantial problem in the construction industry [20]. Nevertheless, an economic organization strives to reduce TC in both the ex-ante and ex-post phase of projects. The literature has proved that TC is reportedly much higher in the ex-post phase of the projects [21-23]. Hence, this study focuses on the ex-post stage of construction projects to explore the risk of TC escalation.

To investigate the problem, this study aims to find the critical risk factor that influences the ex-post TC in construction projects, which Li et al. [21] identified as a research gap for further analysis. There are three objectives of this research. The first objective is the identification of critical risk factors in the construction industry. The second objective is the classification and assessment of risk factors according to the relative importance of industry professionals. The third objective is to provide implications and recommendations to the industry professional for overcoming the risk of TC escalations. The current research has applied partial least structural equation modeling (PLS-SEM), a multivariate analysis tool, to address the issue $[24,25]$. The study is conducted in Pakistan, which can provide complementary and crucial information to classify the critical risk factors. This classification helps the allocation of appropriate risk at the beginning of projects, which significantly adds value in project design to lower the probabilities of TC escalation issues and to make the contracting process more cost efficient. The practitioners and planners will prioritize the risk based on the findings and allocate realistic contingencies in budgetary plans to overcome life cycle cost issues in the construction projects. It will also help policy makers to review policy within organizations to bring sustainability to project operations.

\section{Literature Review}

\subsection{Risk Identification for Ex-Post Transaction Cost}

All construction projects are economically risky, especially projects in developing countries [26]. Creedy et al. [17] found that project cost changed as a result of many related factors, which were closely linked to a specific form of risk. In a similar line, Williamson [2] argued that economic transaction is prone to different kinds of risk, which carry TC, providing the basis for this study. However, 
studies have described that risk has a positive and negative influence on project objectives [27]. This study perceives risk, which possesses hazard and danger that negatively influence to economize any transaction. It means higher risk increases TC, which leads to a higher risk of contract failure [28]. Aligned with this argument, the classification of risk is a primary consideration for risk assessment. Sfakianaki et al. [29] described that construction projects are vulnerable to higher risk and are exposed to internal and external events. Numerous studies applied hierarchical risk breakdown structures. They have broadly categorized risk into internal risk and external risk [18,19], as shown in Figure 1. Internal risk is controllable whereas external risk is uncontrollable [5].

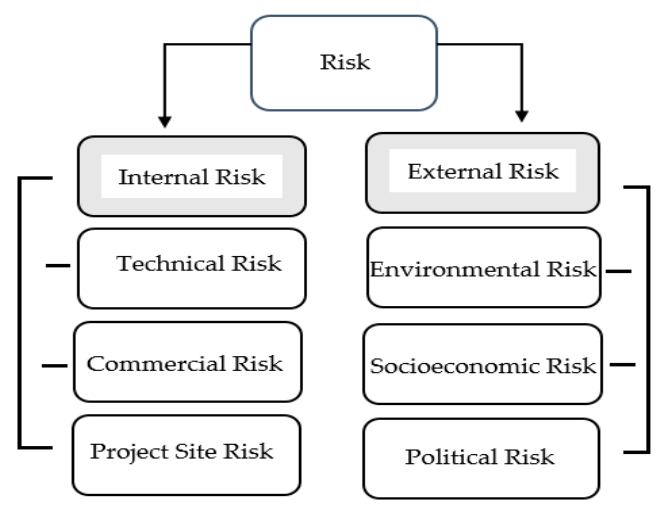

Figure 1. Classification of risk.

\subsubsection{Internal Risk for Ex-Post Transaction Cost}

The internal risks originated to the organization due to organizations' policies, rules and regulations, structure, processes, behavior, actions, culture, and decisions [30]. The internal risk is further classified into technical risk, commercial risk, and project sites risk.

Jaafari [1] described technical risk as the probability that the project does not perform according to the professional standards. In the literature, many authors mentioned how technical risk is exposed to escalating cost in projects. For instance, in an investigation, it was found that unclear contract provisions, and design errors and omissions are sometimes misleading due to a shortage of information and specifications in the project documents, which enhances the probability of additional claims from opportunistic contractors [5]. Similarly, vague project scope and contradiction in contract documents increase the risk that contractors during project operations ask for further claims of cost [3,5]. Shane et al. [5] examined the cost escalation factors of construction projects in Holland; however, one of the causes identified was the procurement approach effect, when the total risk is transferred to the contractor. The contractors respond to these risks by increasing the chances of contingency claims and markups from projects site. In a study, Siemiatycki [31] found that owners' inadequate investigation and preparation for project tendering due to time limitations increases chances for various ex-post changes and, consequently, contractor demand claims, which enhance TC. Shane et al. [5] found that ex-post project schedules change due to challenging design and budgetary issues. In turn, contractors face inflationary problems, which increase the probability the rate revisions and time extensions may be demanded from the project site.

The commercial risk arises due to the supply of resources (financial, material, and human) between the trading partners during project operations [32]. The literature has described various activities which enhance the risk for TC escalation. For instance, Ozorhon et al. [33] researched joint ventures of construction projects, and found that delay payments may discontinue the project work progress, and, consequently, the risk of frequent claims were expected from the project site [33]. Efficient communication between the trading partners reduce the chances of uncertainty and helps them to undertake responsibilities smoothly [34], while inefficient communication increases uncertainty and the probability of TC escalation. In a study, Li et al. [35] ascertained that conflicts between the trading partners might end up in disputes, which enhanced the risk of numerous file claims from the projects 
sites. Also, delay actions in projects [36], incentive payments to increase contractor performance [31], and lack of coordination between the contracting parties enhance the probability that the projects incur additional cost to the owner [37], hence the possibility of TC increases. Moreover, the lack of trust between the trading partners necessitates the owner to employ additional resources for monitoring and control of the untrusted contractor, which increases the chances of TC escalation [10].

There are various risks associated with project sites which cause an increase of the risk of TC escalation to the owner. Gkritza and Labi [6] found that in unstable economies, frequent change of the economic conditions destabilizes the prices of material and also cause labor shortages, which extend the discrepancy between actual and estimated costs, thus increasing the risk of TC escalation. In the process of project execution, contractor efficiency is necessary to keep tight project scheduling; project schedule extensions may easily fall prey to rate revisions [20], which can escalate the risk of TC. The lack of trust between the contracting parties is manifested from delay payments and frequent change orders [11]; similarly, project uncertainty alters the projects' initial information and specification [35], in both the cases, maintaining initial cost is risky and cause enhancements of TC. Li et al. [15] studied the factors that affect TC and argued that frequent changes of working conditions during project operations increases claims and demands from the project site, hence the probability of additional cost to the owner increases.

\subsubsection{External Risk and Ex-Post Transaction Cost}

External risks are generated outside of the organization due to environmental, socioeconomic, and political factors on which organizations have no or very little control, and thus influence the TC [29].

Most construction projects are operated in the natural environment and are exposed to the risk of external influences due to which projects' schedules get delayed. It increases the probability that the contractor will ask for schedule extensions and rate revisions [20]. For instance, Shane et al. [5] asserted that unforeseen events, such as earthquakes, floods, and disaster, etc., increase the probability of significant repairs and reworks. It increases the chance that contractors may request for the claims. Likewise, contracts have provisions in the clauses to make contingency payments [38] for various unforeseen events, such as unexpected excavation, compaction, and structure foundation, which were unknown during the project planning and design phase. This situation enhances the risk that a contractor asks for claims during project operations [5]. Chaturvedi et al. [39] investigated labor productivity in the Indian construction industry and found labor strike was a critical excusable delay factor on which time extension was granted. Such delays may increase the chances that the contractor may request rate revisions. The severe climatic conditions jeopardize the project schedule and work progress. Thus, project instability may enhance the probability that the contractor asks for rate revision [40].

Socio-economic risk is another significant external risk factor. The criminal act is a sub-risk, which incurs losses to the projects, and it enhances the probability that the trading partner demands compensatory payments from the owner [19]. Shane et al. [5] studied the cost escalation factors and identified that inflation causes differences between the estimated cost and actual cost on a project site, and it increases risks that the contractor asks the rate revisions during project execution. The social and environmental factors are unpredictable during project operations. Once they occur, the contractors opportunistically demand compensatory payments, which causes an increase in TC. For instance, building construction projects benefit the communities, while at the same time, they create health hazards if the construction waste is not adequately treated [41]. The stakeholders, such as residents, government, business community, and environmental groups, demand to overcome the negative influence of waste to the society, which requires both parties to take drastic measures; hence, this increases the probability of additional costs [5].

Political risk arises when government laws, legislative systems, regulations, and policy change are due to improper administrative systems [42]. Cheung et al. [43] investigated construction disputes and found that changes of regulation are not controllable, which increases the chances that contractors ask 
for further claims. Similarly, political uncertainty in a country enhances the cost of doing business due to frequent work stoppages and delays on project sites, which provide contractors with legitimacy to request for a rate revision [44], hence increasing the risk of cost escalation. Adeleke [45] and Jaafari [1] studied various types of risks and found the law and order situation as one of the critical risk factors. The law and order situation is created due to political force majeure, such as religious turmoil, riots, terrorism, wars, strikes, civil unrest, and invasions, which influence the project's progress, hence, increasing the chances of TC escalation. Table 1 identifies various risk factors from the literature that escalate TC in construction projects.

Risk is associated with the transactions in construction projects which escalate TC. The discussion in the literature review has provided us with enough evidence on how risk influences the ex-post TC. On this basis, sources of risks can be distinguished into two main streams as shown in Figure 2 . The conceptual model also indicates that risks are further classified in six substreams, as shown in Figure 3. These risks can originate from one or more than one sources and initiate either from the ex-ante or ex-post phase. However, the primary contention is that in all cases, risks are associated with the transaction that escalates ex-post TC. The literature has discussed various transactions in projects, but largely ignored identification of the critical risk factors that increase TC in construction projects. This study is conducted to assess the significant sources of risks that sufficiently increase the TC in the construction industry of Pakistan.

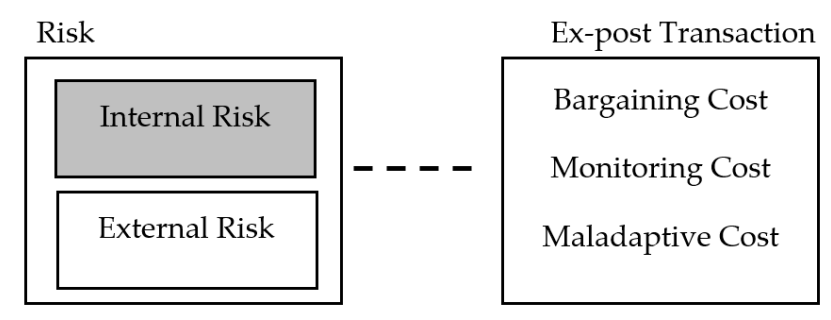

Figure 2. Study framework.

\subsection{Classification of Ex-Post Transaction Cost}

The definitions of ex-post TC is highly fragmented in the literature. For instance, Ho et al. [46] defined costs, which are required for ex-post monitoring, quality checking, negotiations, scheduling, dispute settlement, coordination, managing distortion, expropriation, and renegotiation. From an organization perspective, TC captures administrative work, monitoring agent claims, managing change orders, administering quality, following schedules, and settling disputes on the project site [21]. Williamson [2] defined it as a cost for monitoring, enforcement, renegotiations, bonding, and sanctioning. However, ex-post TC in this study follows Dahlstrom and Nygaard's [47] distribution, which is broadly divided into three significant components, such as monitoring cost (MC), maladaptive cost (MaC), and bargaining cost (BC), as shown in Figure 2.

\subsection{Conceptual Model and Hypothesis Development}

This research is conducted to evaluate the risk of TC escalation in construction projects. Therefore, a conceptual model was designed. SEM is the most suitable technique to analyze complex interactions among different variables [48-50]. SEM is considered a flexible method that is applied for the relationship among several variables, such as direct, indirect, and interactive relationships, and is also used to confirm the underlying structure among latent and observed variables [51]. In the literature, various studies have applied PLS-SEM to address the risks in projects [45,52,53]. Along with this similar line of inquiry, this study has used the SEM model for risk identification and assessment, which influence TC. Moreover, the possible relationship between risk and TC have been shown in the literature $[7,28,54,55]$. The literature has been unable to establish which risk factor is critical to escalate the ex-post TC in construction projects. Hence, the following hypotheses were drawn between risk and TC, as shown in Figure 3. 
Hypothesis H1. Internally driven risks substantially enhance TC in construction projects.

Hypothesis H1a. Technical risk factors positively influence internal risk.

Hypothesis H1b. Commercial risk factors positively influence internal risk.

Hypothesis H1c. Project site risk factors positively influence internal risk.

Hypothesis H2. Externally driven risks substantially enhance TC in construction projects.

Hypothesis H2a. Environmental risk factors positively influence internal risk.

Hypothesis H2b. Socio-economic risk factors positively influence internal risk.

Hypothesis H2c. Political risk factors positively influence internal risk.

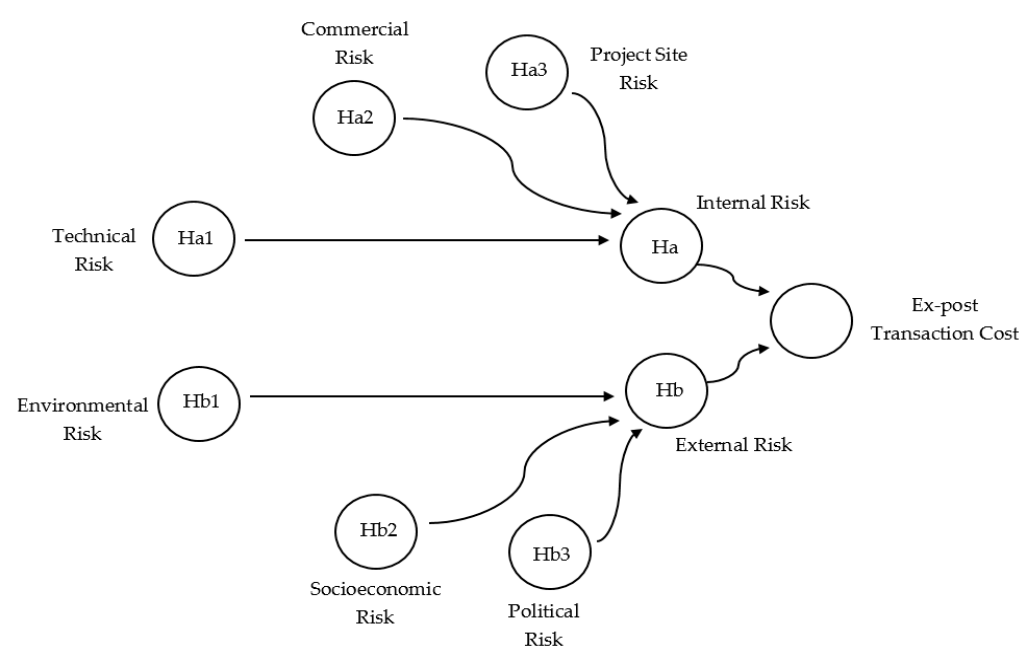

Figure 3. Conceptual model.

\section{Research Methodology}

In this research, the philosophical stance of positivist epistemology was chosen, which is consistent with the objective of the study for testing the proposed hypotheses. The proposed philosophical position considers reality objectively, which can be realized empirically [56]. However, in this research, the survey method was used for the quantitative data collection to achieve the positivist goal as suggested by Saunders et al. [56]. The survey questionnaires were filled by experts of the Pakistani public sector construction industry, and the data collection was performed following the three steps described in Figure 4.

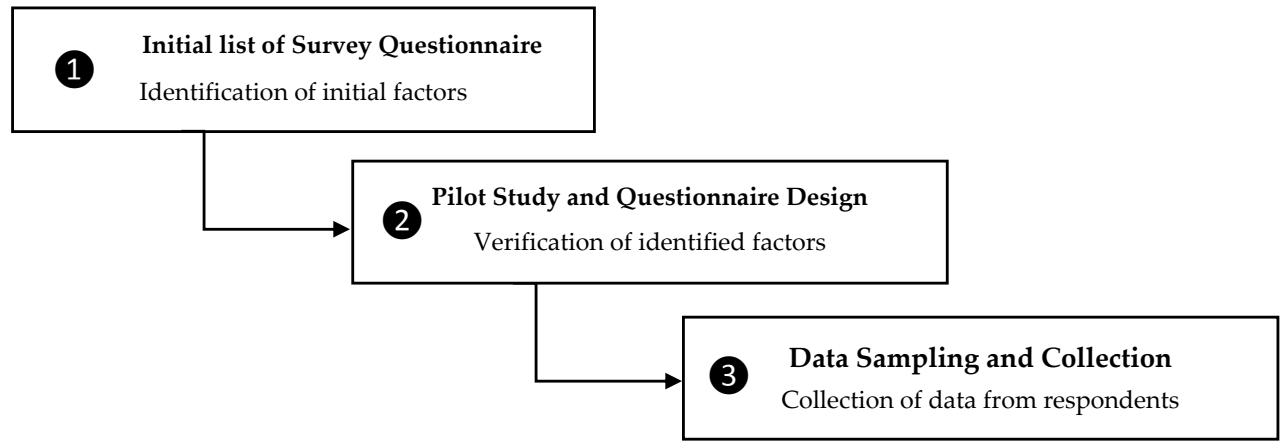

Figure 4. Data collection process. 


\subsection{Initial List of Survey Questionnaire}

The preparation of the survey questionnaire was started with the investigation of potential risk factors from the related literature that escalate ex-post TC in the construction industry. The initial literature review pointed out several variables, which potentially increase the risk of TC escalation. The first round of literature review from books and research papers enabled us to find 48 preliminary variables that were supposed to enhance the risk of TC.

\subsection{Pilot Study and Questionnaire Design}

The factors identified from the literature review were investigated through interviews with construction experts and academics. The survey was directed through face to face personal interviews to examine the information correctness, and to develop an understanding of the identified factors a questionnaire was composed. It was assured that the practitioners and academics had work experience of more than 15 years in managerial positions and had worked with a different project in the construction industry. We invited 10 practitioners, such as project managers and executive engineers, that had enough on hand practical experience, currently supervising more than hundreds of projects. Also, four academics were called for interviews. Among them, two Professors and two Associate Professors participated in making the final version of the survey questionnaire. They were given freedom to make the required changes on the questionnaire, such as deletion and addition, as appropriate. During the interaction, respondents were also requested to consider indigenous cultural scenarios of construction projects. The interview participants deleted six factors from the provided list and made a final list of survey questionnaire comprised of 42 questions, as shown in Table 1.

Table 1. Identification of factors from the literature.

\begin{tabular}{|c|c|c|}
\hline Risk Factors & Code & References \\
\hline \multicolumn{3}{|l|}{ Internal Risk } \\
\hline \multicolumn{3}{|l|}{ Technical Risk } \\
\hline Ambiguous contract provisions & INTTech1 & [5] \\
\hline Poor project estimation & INTTech2 & [5] \\
\hline Scope vagueness & INTTech3 & [57] \\
\hline Procurement approach effect & INTTech4 & [5] \\
\hline Competitive Tendering & INTTech5 & {$[14]$} \\
\hline Contract document conflicts & INTTech6 & [20] \\
\hline Change orders & INTTech7 & [58] \\
\hline Project design errors & INTTech8 & [6] \\
\hline Inadequate investigation and preparation & INTTech9 & [31] \\
\hline Project schedule changes & INTTech10 & [5] \\
\hline \multicolumn{3}{|l|}{ Commercial Risk } \\
\hline Quality of communication & INTCom1 & [34] \\
\hline Qualification of contractor & INTCom2 & [21] \\
\hline Conflict Management & INTCom3 & [35] \\
\hline Monitoring and control & INTCom 4 & [10] \\
\hline Delay payments & INTCom5 & [33] \\
\hline Environmental instability & INTCom6 & [14] \\
\hline Incentive Payments & INTCom7 & [31] \\
\hline Coordination cost & INTCom8 & [10] \\
\hline \multicolumn{3}{|l|}{ Project Site Risk } \\
\hline Material and Labor shortage & INTPro1 & [6] \\
\hline Poor contract management & INTPro2 & [59] \\
\hline Faulty scheduling & INTPro3 & [20] \\
\hline Project Uncertainty & INTPro4 & {$[15]$} \\
\hline Frequency of claims & INTPro5 & [15] \\
\hline
\end{tabular}


Table 1. Cont.

\begin{tabular}{|c|c|c|}
\hline Risk Factors & Code & References \\
\hline \multicolumn{3}{|l|}{ External Risk } \\
\hline \multicolumn{3}{|l|}{ Environmental Risk } \\
\hline Labor strike & EXTEnv1 & [39] \\
\hline Project stability & EXTEvn2 & [6] \\
\hline Unforeseen events & EXTEvn3 & [5] \\
\hline Unforeseen conditions & EXTEvn4 & [5] \\
\hline \multicolumn{3}{|l|}{ Socio-Economic Risk } \\
\hline Criminal act & EXTSoeco1 & [19] \\
\hline Inflation & EXTSoeco2 & [19] \\
\hline Local stakeholders' concerns & EXTSoeco3 & [5] \\
\hline \multicolumn{3}{|l|}{ Political Risk } \\
\hline Change of Regulation & EXTPol1 & {$[43]$} \\
\hline Political Uncertainty & EXTPol2 & {$[29,44]$} \\
\hline Political force Majeure & EXTpol3 & {$[1,45]$} \\
\hline \multicolumn{3}{|l|}{ Ex-post Transaction cost } \\
\hline Monitoring cost & MC & \\
\hline Cost for monitoring citizen and civil societies' complaints & - & [28] \\
\hline Cost for analyzing the contractor data & - & [28] \\
\hline Cost for contractor's auditing & - & [28] \\
\hline Maladaptive Cost & $\mathrm{MaC}$ & \\
\hline Errors in project documentation & - & {$[5,60]$} \\
\hline Contract documents conflict & - & [20] \\
\hline Incomplete design and specifications & - & [43] \\
\hline Bargaining Cost & $\mathrm{BC}$ & \\
\hline Design changes & - & [58] \\
\hline Work Acceleration & - & {$[4]$} \\
\hline Extra work & - & [40] \\
\hline
\end{tabular}

\subsection{Data Sampling and Collection Procedure}

Table 2 shows the demographic information of the respondents. The respondents were selected from the public-sector construction industry of Pakistan. The organizations are the Public Works Department (PWD), Water and Power Development Authority (WAPDA), and Capital Development Authority (CDA). The target respondents were Executives, Project Managers, Project Engineers, Associate Engineers, Architects, and consultants, who worked in the sampled organization and had enough experience in the construction related industry. The identified public-sector organizations are the largest in the country, which contains a significant proportion of respondents.

However, a survey questionnaire was divided into two sections. The first section of the questionnaires carried out demographic information (experience, designation, qualification, and organization) of the respondents. The second section was comprised of critical questions on which respondents were asked to respond. Thus, in line with Guo et al. [16], a five-point Likert scale, such as 1 (strongly agree) to 5 (strongly disagree), was used to identify respondents' opinions on the questionnaire. In survey research, there are various ways to approach respondents for data collection, such as emails, telephone, self-administered, and interviews [41]. This research used a self-administered (hand delivered) survey. The organizations for data collection were initially identified from personal sources and websites, and then the sample was selected from these organizations. A simple random sampling procedure was employed to choose the sample. The distribution of the final version of the survey questionnaire was made during March and April 2018 from Pakistan. The total number of questionnaires distributed 
among the target population was 510. The total number of questionnaires returned and used for data analysis was 475 , showing a response rate of $76 \%$, which is considered excellent [61].

Table 2. Respondents' profile.

\begin{tabular}{cccc}
\hline & & Total No & Percentage \\
\hline \multirow{5}{*}{ Experience } & Years 5> & 103 & 22 \\
& $10>$ & 302 & 64 \\
Qualification & $20>$ & 70 & 15 \\
& PhD & 0 & 0 \\
& Masters & 98 & 21 \\
& Bachelors & 345 & 73 \\
& Diploma & 32 & 7 \\
\hline \multirow{5}{*}{ Designation } & Executive Engineer & 45 & 9 \\
& Project Manager & 72 & 15 \\
& Project Engineer & 150 & 32 \\
& Associate Engineers & 101 & 21 \\
& Architects & 40 & 8 \\
& Consultants & 67 & 14 \\
\hline \multirow{5}{*}{ Organizations } & PWD & 136 & 29 \\
& WAPDA & 221 & 47 \\
& CDA & 118 & 25 \\
\hline
\end{tabular}

\section{Data Analysis}

The hypothesized model, as shown in Figure 3, was tested and analyzed using SmartPLS version 3.2.7. Its application to find the relationship between the latent and manifest variables has several advantages over regression-based methods [62]. The evaluation of PLS can be performed in two phases. First, the assessment of the outer measurement model is carried out, and, second, is the evaluation of the inner structural model [63].

\subsection{Measurement Model Assessment}

PLS-SEM in research provides an opportunity to test reliability and discriminate validity during scale development through confirmatory factor analysis [51]. The outer model assessment aims to calculate the reliability and validity of the observed variables and latent variables. There are four types to assess the reliability and validity of the measurement model, such as internal consistency reliability, construct reliability, convergent validity, and discriminant validity [64].

SmartPLS assesses the internal consistency reliability and provides values for Cronbach's alpha and composite reliability (CR) in the model, as shown in Table 3 . The values above 0.70 are acceptable [64]; thus, all values in the construct of our model meet the threshold criteria for CR. Although both Cronbach's alpha and CR are used for construct reliability, CR is always preferred because it involves sensitivity to the number of items. The outer loading of variables (observable) on the corresponding variable (latent) greater than 0.70 is desirable for indicator reliability [65]. Table 3 shows the outer loading between the ranges of 0.776 to 0.899 . Hence, indicator reliability is achieved. To measure convergent validity, the average variance extracted (AVE) is calculated $[25,66]$. The standard acceptance criteria for convergent validity is that the AVE for all the construct should be greater than 0.50 [25]. Table 3 illustrates the values, which confirm the reliability and validity of the measurement model. 
Table 3. Validity and reliability.

\begin{tabular}{|c|c|c|c|c|c|}
\hline & Item & Loading & Cronbach's Alpha & (AVE) & CR \\
\hline \multirow{3}{*}{ Bargaining Cost } & BC1 & 0.843 & 0.830 & 0.747 & 0.899 \\
\hline & BC2 & 0.873 & - & - & - \\
\hline & BC3 & 0.876 & - & - & - \\
\hline \multirow{3}{*}{ Maladaptive Cost } & MC1 & 0.858 & 0.820 & 0.737 & 0.893 \\
\hline & MC2 & 0.883 & - & - & - \\
\hline & MC3 & 0.802 & - & - & - \\
\hline \multirow{3}{*}{ Monitoring Cost } & $\mathrm{MaC1}$ & 0.888 & 0.805 & 0.720 & 0.885 \\
\hline & $\mathrm{MaC2}$ & 0.899 & - & - & - \\
\hline & $\mathrm{MaC} 3$ & 0.783 & - & - & - \\
\hline \multirow{10}{*}{ Technical Risk } & INTTech1 & 0.797 & 0.945 & 0.669 & 0.953 \\
\hline & INTTech2 & 0.836 & - & - & - \\
\hline & INTTech3 & 0.832 & - & - & - \\
\hline & INTTech4 & 0.855 & - & - & - \\
\hline & INTTech5 & 0.844 & - & - & - \\
\hline & INTTech6 & 0.800 & - & - & - \\
\hline & INTTech7 & 0.807 & - & - & - \\
\hline & INTTech8 & 0.776 & - & - & - \\
\hline & INTTech9 & 0.817 & - & - & - \\
\hline & INTTech10 & 0.813 & - & - & - \\
\hline \multirow{8}{*}{ Commercial Risk } & INTCom1 & 0.843 & 0.932 & 0.677 & 0.944 \\
\hline & INTCom2 & 0.807 & - & - & - \\
\hline & INTCom3 & 0.830 & - & - & - \\
\hline & INTCom4 & 0.814 & - & - & - \\
\hline & INTCom5 & 0.857 & - & - & - \\
\hline & INTCom6 & 0.794 & - & - & - \\
\hline & INTCom7 & 0.816 & - & - & - \\
\hline & INTCom8 & 0.820 & - & - & - \\
\hline \multirow{5}{*}{ Project site Risk } & INTPro1 & 0.831 & 0.896 & 0.707 & 0.923 \\
\hline & INTPro2 & 0.857 & - & - & - \\
\hline & INTPro3 & 0.818 & - & - & - \\
\hline & INTPro4 & 0.847 & - & - & - \\
\hline & INTPro5 & 0.850 & - & - & - \\
\hline \multirow{4}{*}{ Environmental Risk } & EXTEnv1 & 0.828 & 0.883 & 0.741 & 0.92 \\
\hline & EXTEnv2 & 0.855 & - & - & - \\
\hline & EXTEnv3 & 0.877 & - & - & - \\
\hline & EXTEnv4 & 0.882 & - & - & - \\
\hline \multirow{3}{*}{ Political Risk } & EXTPol1 & 0.823 & 0.830 & 0.746 & 0.898 \\
\hline & EXTPol2 & 0.868 & - & - & - \\
\hline & EXTPol3 & 0.899 & - & - & - \\
\hline \multirow{3}{*}{ Socio-Economic Risk } & EXTSoeco1 & 0.872 & 0.854 & 0.774 & 0.911 \\
\hline & EXTSoeco2 & 0.883 & - & - & - \\
\hline & EXTSoeco3 & 0.884 & - & - & - \\
\hline
\end{tabular}

The discriminant validity can be assessed using three approaches, such as cross loading, Fornell and Larker criteria [66], and the heterotrait-monotrait (HTMT) ratio [67]. For external consistency assessment of a model, first, cross-loadings were scrutinized, which found that there were no indicator loads higher than the opposing construct [67]. The second measure is the Fornell and Larcker criterion test, which describes that square root of AVE, and this should be higher than its correlation with any other latent constructs in a model. Table 4 shows that the correlation of latent constructs is smaller than the square root of AVE along the diagonal, which confirms the satisfactory discriminant validity. Moreover, the latest criterion to confirm discriminant validity is HTMT [67], which was also calculated. An HTMT value higher than 0.85 , as a rule of thumb, is considered a potential problem for 
the discriminant validity [64]. Table 5 shows that all the values are less than 0.85 , which confirms the discriminant validity.

Table 4. Fornell and Larcker criterion.

\begin{tabular}{cccccccccc}
\hline & BC & ComR & ER & MaC & MC & PR & PSR & SR & TR \\
\hline BC & $\mathbf{0 . 8 6 4}$ & - & - & - & - & - & - & - & - \\
ComR & 0.305 & $\mathbf{0 . 8 2 3}$ & - & - & - & - & - & - & - \\
ER & 0.294 & 0.157 & $\mathbf{0 . 8 6 1}$ & - & - & - & - & - & - \\
MaC & 0.058 & 0.319 & 0.289 & $\mathbf{0 . 8 5 8}$ & - & - & - & - & - \\
MC & 0.107 & 0.313 & 0.308 & 0.033 & $\mathbf{0 . 8 4 9}$ & - & - & - & - \\
PR & 0.284 & 0.166 & 0.217 & 0.274 & 0.333 & $\mathbf{0 . 8 6 4}$ & - & - & - \\
PSR & 0.320 & 0.215 & 0.114 & 0.293 & 0.308 & 0.160 & $\mathbf{0 . 8 4 1}$ & - & - \\
SR & 0.280 & 0.138 & 0.210 & 0.308 & 0.304 & 0.176 & 0.147 & $\mathbf{0 . 8 8 0}$ & - \\
TR & 0.310 & 0.231 & 0.125 & 0.312 & 0.298 & 0.175 & 0.236 & 0.143 & $\mathbf{0 . 8 1 8}$ \\
\hline
\end{tabular}

Note 1: MC, Monitoring cost; BC, Bargaining Cost; MaC, Maladaptive Cost; PR, Political Risk; PSR, Project Site Risk; ER, Environmental Risk; ComR, Commercial Risk; SER, Socioeconomic Risk; TR, Technical Risk. The square root of AVE is indicated as a bold value on the diagonal in the table. Note 2: Bold values indicate the square root of AVE.

Table 5. HTMT.

\begin{tabular}{cccccccccc}
\hline & BC & ComR & ER & MaC & MC & PR & PSR & SR & TR \\
\hline BC & - & - & - & - & - & - & - & - & - \\
ComR & 0.347 & - & - & - & - & - & - & - & - \\
ER & 0.342 & 0.172 & - & - & - & - & - & - & - \\
MaC & 0.070 & 0.365 & 0.343 & - & - & - & - & - & - \\
MC & 0.129 & 0.361 & 0.365 & 0.051 & - & - & - & - & - \\
PR & 0.343 & 0.189 & 0.247 & 0.335 & 0.406 & - & - & - & - \\
PSR & 0.371 & 0.236 & 0.131 & 0.343 & 0.365 & 0.184 & - & - & - \\
SR & 0.332 & 0.154 & 0.239 & 0.370 & 0.369 & 0.203 & 0.166 & - & - \\
TR & 0.350 & 0.245 & 0.137 & 0.357 & 0.341 & 0.196 & 0.256 & 0.160 & - \\
\hline
\end{tabular}

\subsection{Structural Model Assessment}

The inner structural model assessment helps to investigate the empirical data to confirm the underlying theory [25]. This study confirms the model validation using different tests on the structural level. The structural model can be assessed using path coefficient value $(\beta)$ and T-statistics, the coefficient of determination $\left(\mathrm{R}^{2}\right)$, predictive relevance $\left(\mathrm{Q}^{2}\right)$, and the goodness of fit (GOF) index.

\subsubsection{The Coefficient of Determination $\left(R^{2}\right)$ Analysis}

$\mathrm{R}^{2}$ is measured on an exogenous latent construct, which predicts the endogenous latent construct. In this study, two exogenous latent constructs (internal and external risk) explain the endogenous construct (ex-post TC). Its representation is shown in three levels, such as weak (0.25), moderate (0.50), and substantial (0.75) [25,65]. In this study, the endogenous latent construct value is $R^{2}=0.76$, which means that the exogenous latent construct explains $76 \%$ of the endogenous latent construct. The model is accurate to explain the endogenous latent construct and is considered substantial because it explains more than $75 \%$ of the variance explained.

\subsubsection{Path Coefficient Estimation and T-Test Estimation}

The path coefficient in PLS-SEM is similar to the regression analysis and standardized beta coefficient ( $\beta$ ) [63]. The significance of the hypothesis is tested by calculating the $\beta$ value of every path on the model, as shown in Figure 5. To test the hypothesis of a model, a greater $\beta$ value depicts the high influence of an exogenous latent construct on the endogenous construct of the hypothesized model. The significance level ( $p$-value) is verified through the T-statistics test on each $\beta$ value of the hypothesized model. In PLS-SEM, on each path coefficient, the significance of the hypothesis can be 
assessed with the help of the bootstrapping method. This study set the bootstrapping sample to 5000 to generate standard-errors, the significance of path coefficient, and T-statistics values [25]. The test result shows the significance of the relationship because all values were found to be above the threshold.

H1a hypothesized that technical risk significantly influences the internal risk. The findings in Table 6 and Figure 3 confirm the significant relationship ( $\beta=0.664, T=21.623, p=0.000)$. Therefore, H1a is supported. That the commercial risk has a positive influence on the internal risk was hypothesized in $\mathrm{H} 1 \mathrm{~b}$. The result substantiates the hypothesis $(\beta=0.468, \mathrm{~T}=18.477, p=0.000)$. Project site risk $(\mathrm{H} 1 \mathrm{c})$ was also predicted to influence the internal risk $(\beta=0.256, \mathrm{~T}=11.081, p=0.000)$, hence, H1c is supported. The primary hypothesis was that internal risk substantially influences ex-post TC $(\beta=0.545, \mathrm{~T}=23.306$, $p=0.000)$, therefore, supporting H1. Furthermore, H2a was that environmental risk positively affects external risk ( $\beta=0.635, T=18.203, p=0.000$ ), which escalates the risk of $T C$, therefore, supporting H2a. Moreover, the results from Table 6 also provide empirical support for $\mathrm{H} 2 \mathrm{~b}$, in which the socioeconomic risk substantially influences the external risk $(\beta=0.411, \mathrm{~T}=13.168, p=0.000)$. Similarly, when observing the influence of political risk on the external risk factor, $\mathrm{H} 2 \mathrm{c}$, the results from Table 6 endorsed and confirm the hypothesis $(\beta=0.393, \mathrm{~T}=13.40, p=0.000)$. The influence of external risk on the escalation of ex-post TC was also significant $(\beta=0.538, \mathrm{~T}=22.92, p=0.00)$, depicting that central hypothesis, $\mathrm{H} 2$, was supported.

Table 6. Path coefficient and T-statistics.

\begin{tabular}{cccccc}
\hline & $\begin{array}{c}\text { Original } \\
\text { Sample } \\
\mathbf{( O )} \boldsymbol{\beta}\end{array}$ & $\begin{array}{c}\text { Sample } \\
\text { Mean } \\
\mathbf{( M )}\end{array}$ & $\begin{array}{c}\text { Standard } \\
\text { Deviation } \\
\text { (STDEV) }\end{array}$ & $\begin{array}{c}\text { T Statistics } \\
(\text { I O/STDEVI) }\end{array}$ & $p$ Values \\
\hline Bargaining Cost $\rightarrow$ Ex-post TC & 0.662 & 0.646 & 0.109 & 6.102 & 0.000 \\
Commercial Risk $\rightarrow$ Internal Risk & 0.468 & 0.463 & 0.025 & 18.477 & 0.000 \\
Environmental Risk $\rightarrow$ External Risk & 0.635 & 0.638 & 0.035 & 18.203 & 0.000 \\
$\quad$ External Risk $\rightarrow$ Ex-post TC & 0.538 & 0.537 & 0.023 & 22.92 & 0.000 \\
Internal Risk $\rightarrow$ Ex-post TC & 0.545 & 0.545 & 0.023 & 23.306 & 0.000 \\
Maladaptive Cost $\rightarrow$ Ex-post TC & 0.413 & 0.394 & 0.175 & 2.355 & 0.019 \\
Monitoring Cost $\rightarrow$ Ex-post TC & 0.521 & 0.496 & 0.120 & 4.347 & 0.000 \\
Political Risk $\rightarrow$ External Risk & 0.393 & 0.390 & 0.029 & 13.400 & 0.000 \\
Project site Risk $\rightarrow$ Internal Risk & 0.256 & 0.252 & 0.023 & 11.081 & 0.000 \\
Socio-Economic Risk $\rightarrow$ External Risk & 0.411 & 0.408 & 0.031 & 13.168 & 0.000 \\
Technical Risk $\rightarrow$ Internal Risk & 0.664 & 0.667 & 0.031 & 21.623 & 0.000 \\
\hline
\end{tabular}

Statistically significant means $(p$-value $<0.05)$ hypothesis accepted.

However, the beta coefficient $(\beta)$ value describes the strength between exogenous and endogenous latent constructs. The higher the value of variance, the higher the effect will be. Table 6 and Figure 5 shows the calculation results and comparison of both internal risk $(\beta=0.545)$ and external risk ( $\beta=0.538)$ on ex-post TC. Both risks significantly influence the risk of ex-post TC. 


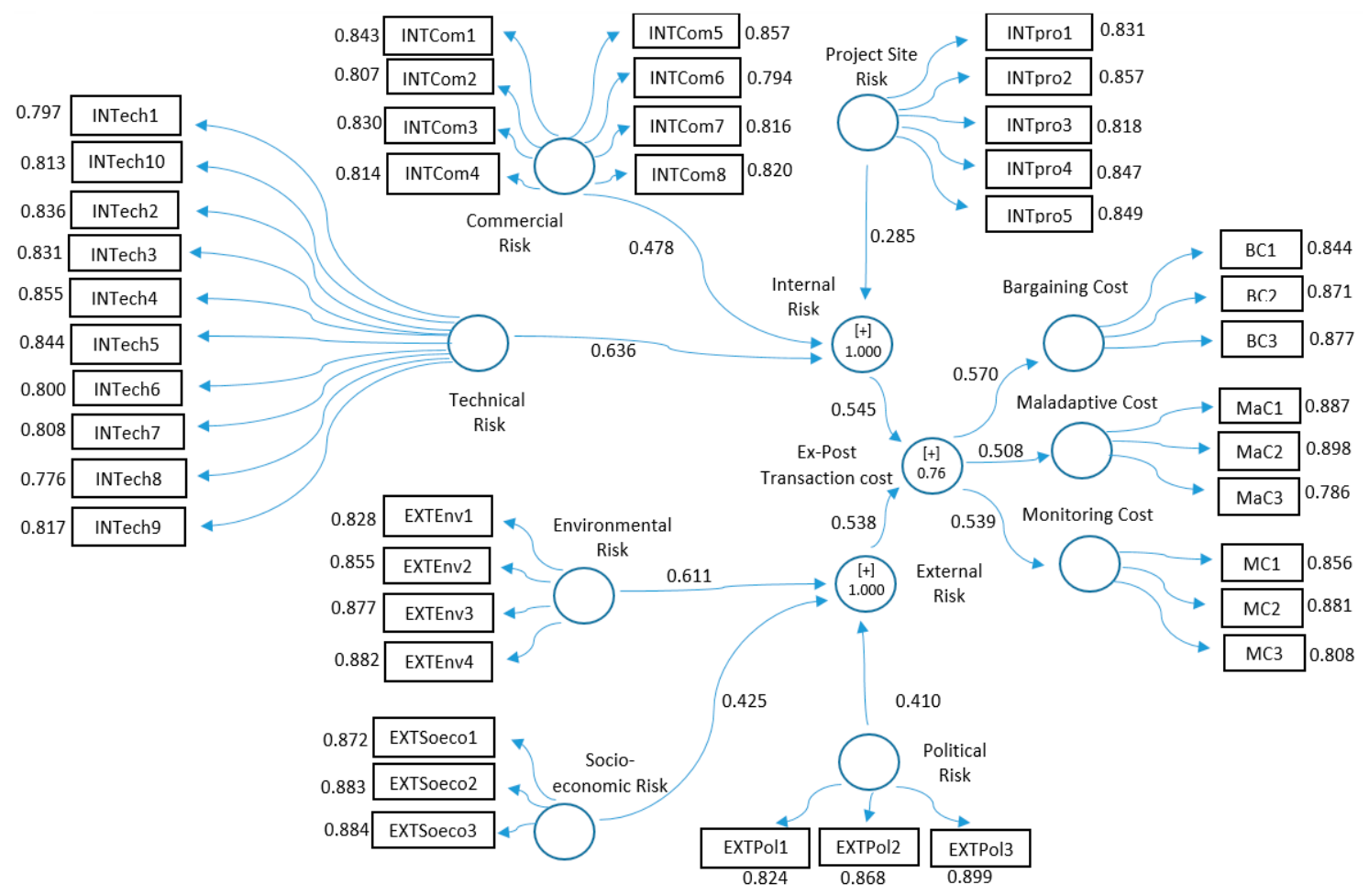

Figure 5. Hypothesis SEM model.

\subsubsection{Predictive Relevance (Q2)}

This test is calculated using the blindfolding technique to measure the quality of the PLS-SEM model [68]. To measure $\mathrm{Q}^{2}$, mainly cross-validated redundancy was applied. The decision on $\mathrm{Q}^{2}$ is that the value higher than zero $(>0)$ for an endogenous construct means that the PLS-SEM model has predictive relevance for a given endogenous construct. Similarly, a value $\leq 0$ indicates that the model is not relevant to predict the given endogenous factor. In this study, the model value was 0.26 ; greater than the standardized threshold and therefore had adequate predictive relevance for the endogenous latent construct.

\subsubsection{Goodness-of-Fit Analysis (GOF)}

According to Tenenhaus et al. [68], the GOF index is used to empirically verify if the proposed model sufficiently explains the empirical data. There is a standardized approach for the validation of a global path model, in which a value between 0 and 1 is interpreted. For instance, a value of $0.10,0.25$, and 0.36 indicates small, medium, and large GOF, respectively, as a measure for global validation of a path model [68]. This study calculated a GOF value of 0.74 , which shows strong validation of the global path to make a model parsimonious and plausible [69].

The data results and analysis provide a vivid understanding of risk and its influence on the ex-post TC. For further facilitation and understanding of the results, regression loading of each latent construct was normalized, calculating the weight of relative importance of each latent construct and sub-constructs, as shown in Table 7. 
Table 7. Standardized regression loading and weight of relative importance.

\begin{tabular}{|c|c|c|c|}
\hline & Hypothesized Variables & Standardized Regression Loading & Weight of Relative Importance (\%) \\
\hline \multirow[t]{14}{*}{ External Risk } & & 0.538 & 49.68 \\
\hline & Environmental Risk & 0.611 & 22.88 \\
\hline & EXTEnv1 & 0.828 & 24.06 \\
\hline & EXTEnv2 & 0.855 & 24.84 \\
\hline & EXTEnv3 & 0.877 & 25.48 \\
\hline & EXTEnv4 & 0.882 & 25.62 \\
\hline & Political Risk & 0.410 & 15.36 \\
\hline & EXTPol1 & 0.823 & 31.78 \\
\hline & EXTPol2 & 0.868 & 33.51 \\
\hline & EXTPol3 & 0.899 & 34.71 \\
\hline & Socio-Economic Risk & 0.250 & 9.36 \\
\hline & EXTSoeco1 & 0.872 & 33.04 \\
\hline & EXTSoeco2 & 0.883 & 33.46 \\
\hline & EXTSoeco3 & 0.884 & 33.50 \\
\hline \multirow[t]{27}{*}{ Internal Risk } & & 0.545 & 50.32 \\
\hline & Technical Risk & 0.636 & 23.82 \\
\hline & INTTech1 & 0.797 & 9.75 \\
\hline & INTTech2 & 0.836 & 10.22 \\
\hline & INTTech3 & 0.832 & 10.17 \\
\hline & INTTech4 & 0.855 & 10.46 \\
\hline & INTTech5 & 0.844 & 10.32 \\
\hline & INTTech6 & 0.800 & 9.78 \\
\hline & INTTech7 & 0.807 & 9.87 \\
\hline & INTTech8 & 0.776 & 9.49 \\
\hline & INTTech9 & 0.817 & 9.99 \\
\hline & INTTech10 & 0.813 & 9.94 \\
\hline & Commercial Risk & 0.478 & 17.90 \\
\hline & INTCom1 & 0.843 & 12.81 \\
\hline & INTCom2 & 0.807 & 12.81 \\
\hline & INTCom3 & 0.830 & 12.61 \\
\hline & INTCom4 & 0.814 & 12.37 \\
\hline & INTCom5 & 0.857 & 13.02 \\
\hline & INTCom6 & 0.794 & 12.07 \\
\hline & INTCom7 & 0.816 & 12.40 \\
\hline & INTCom8 & 0.82 & 12.46 \\
\hline & Project Site Risk & 0.285 & 10.67 \\
\hline & INTPro1 & 0.831 & 19.77 \\
\hline & INTPro2 & 0.857 & 20.39 \\
\hline & INTPro3 & 0.818 & 19.46 \\
\hline & INTPro4 & 0.847 & 20.15 \\
\hline & INTPro5 & 0.850 & 20.22 \\
\hline
\end{tabular}

Bold numbers represent latent variables.

\section{Discussion}

The SEM model found that both internal risk and external risk factors significantly influence ex-post TC. The two latent variables, such as technical risk and environmental risk, have the highest weight of relative importance on ex-post TC at $23.82 \%$ and $22.88 \%$, respectively. The internal risk factor was described by 10 sub-criterion: Procurement approach effect (weight of relative importance $10.46 \%)$, competitive tendering $(10.32 \%)$, poor project estimation $(10.22 \%)$, unclear work scope $(10.17 \%)$, inadequate investigation and preparation $(9.99 \%)$, project schedule changes $(9.94 \%)$, change orders $(9.87 \%)$, contract document conflicts $(9.78 \%)$, ambiguous contract provisions $(9.75 \%)$, and project design errors $(9.49 \%)$, as shown in Table 7 . The internal risk may take any form, which arises due to human involvement [70]. In this study, technical risk factors have been considered one of the essential factors, possibly because infrastructure projects are highly complex, sensitive, and difficult to execute. There are various technical deficiencies left in the ex-ante phase of projects, such as feasibility study, geological survey, tender estimation, design and drawing, risk assessment, environmental assessment, and consultant selection [71], which enhance the risk of escalating ex-post TC in projects. These findings are consistent with the studies in different countries, which considered a lack of technical skills in 
procurement management as detrimental to controlling project costs [22,72]. Ferris and Graddy [73] argued that project contracting as a public service delivery choice for the government is primarily to save production and TC. However, this study finds the role of human capacity as an essential risk factor for controlling ex-post TC due to which total project costs increase.

The environmental risk impact on ex-post TC has been considered another vital risk factor, which has the highest weight of relative importance. The respondents found this risk factor critical because construction projects are usually executed outdoors in a natural environment. These projects are exposed to various unexpected uncertainties on which the owner has little or no control [74]. This construct was described by four sub-criteria, such as unforeseen condition (weights of relative importance: $25.62 \%$ ), unforeseen events (25.48\%), inclement weather conditions (24.84\%), and labor strike $(24.06 \%)$, as shown in Table 7 . The environmental risk on the TC escalation has been considered the second most important risk factor that influences TC. This is an excusable risk factor on which the majority of the construction projects have written clause provisions to compensate the losses. It is obvious externally driven risk exists, which is a fundamental source of TC escalation that all the construction project participants should consider at the outset of contracting. The sub-criteria, unforeseen events and conditions, inclement weather condition, and labor strike, can enhance the risk of TC escalation to the owner. This finding agrees with Shane et al. [5], Gkritza and Labi [6], and Maqbool and Sudong [75]. The probable justification of the respondents to place this construct on top of the external risk factor is because organizations' written clause provisions are unable to control contractors' opportunistic behavior. The risk from the external environment may provide opportunistic contractors enough leverage to acquire maximum claims from contingencies and compensation provisions.

The project site risk and socio-economic risk are the least influencing risks on ex-post TC, and both have the lowest weights of relative importance at $10.67 \%$ and $9.36 \%$, respectively, as shown in Table 7 . Project site risk was described by four sub-criteria: Poor contract management (weight of relative importance: $20.39 \%$ ), dispute on claim evaluation (20.22\%), project environment uncertainty $(20.15 \%)$, faulty scheduling $(19.77 \%)$, and material and labor shortages $(19.46 \%)$. Similarly, socio-economic risk was the second lowest important risk factor, which was described by three sub-criteria: Local stakeholders' concerns (weights of relative importance: $33.50 \%$ ), inflation (33.46\%), and criminal act (33.04\%). Notwithstanding, project site risk and socioeconomic risk had the lowest weight in the overall weight of relative importance, but respondents considered these variables important as they can enhance the chance for ex-post TC. The possible explanation for placing these constructs lowest is that the projects are contracted out through formal contracting and there is little risk that the opportunistic contractors ask for claims, hence low chances of TC escalation. The owner can have an arm length relationship with the contractor if the contractual obligations are not met during the project duration. This finding is consistent with Brown and Potoski [76]. However, it provides the opportunistic contractor with fewer opportunities to forward claims from these sources. When terms violation occurs, either party has a right to settle down those issues privately or otherwise such matters are settled in courts.

The latent variables that measures the ex-post TC is bargaining cost, monitoring cost, and maladaptive cost. Bargaining cost (weights of relative importance: $35.25 \%$ ), monitoring cost, $(33.33 \%)$, and maladaptive cost $(31.42 \%)$. The risks substantially influence the ex-post TC, which is mainly incurred due to ex-post modification, renegotiations, and adjustments.

\section{Conclusions}

Construction projects are complex endeavors and are executed in natural environments. Although TC escalation issues were discussed in the literature, the risk of TC escalation was not well captured. This study has evaluated and assessed the risks of ex-post TC escalation of construction projects. In this study, 475 surveys were conducted in the construction industry in Pakistan. The risks were broadly described by being internal or external to the organization, which was further classified into 
six sub-categories. The maladaptive costs, bargaining costs, and monitoring costs represented the ex-post TC. The risks in the organizations were hypothesized to find their influence on TC escalation using the PLS-SEM model. The results showed that all the sub-hypothesized risks were positively related to both internal and external risks. Moreover, both leading hypothesized risks, such as internal and external risks, also positively influenced ex-post TC. This study clarifies our understanding as explained below.

1. Both the technical risk and environmental risk are very critical to escalate TC. The internal risk is a controllable risk. The owner can mitigate internal risk by concentrating on the procurement management to deal with the technical issue. This study found that factors, such as the procurement approach effect, competitive tendering process, and realistic cost estimation in the procurement phase, are more significant to control ex-post TC escalation. The risk of the procurement approach effect, if not adequately addressed, results in all project risk being transferred to the trading partner. The partner offsets the risk opportunistically with markup claims during an uncertainty situation, hence the risk of TC escalates. In this situation, human skills are fundamental to deal with technical issues. For instance, the competitive tendering process needs to incorporate correct details analysis and investigation of contractors before contracting the projects. Similarly, the environmental risk was also found to significantly escalate TC. To overcome the influence of risk from the uncontrollable environment, owners should discourage opportunistic contractors through strict policies on the written contingency clauses. This control can be further strengthened if formal and informal supervisory mechanisms are adapted to stop the opportunistic contractor from getting unjustified compensatory claims.

2. In project risks, mitigation requires risk classification and an understanding of the magnitude of all risks from different sources. This study has classified the sources of risk and confirm that the most important sources of risk are derived from technical and environmental origins. The project participants can focus on these critical sources of risk and rank them to make a possible strategy to mitigate it. The project designer can bear some additional ex-ante TC on each source of risk to reduce ex-post TC escalation.

Furthermore, this research contributes to the literature by undertaking a decomposition of risks and its influence on TC. The risks are not entirely removed, but can be minimized if the potential risk associated with the different phases and separate entities in projects are ascertained in advance. Before controlling the cost, it is imperative to understand the internal strength of risk and its external influences, which were demonstrated in this research. This study provides a foundation stone for the project practitioners, designers, and consultants, shifting their attitude from risk mitigation to risk optimization while dealing with the risk of TC issues.

The findings of this research imply that the Pakistani construction industry needs to work on the internal capacity development of the technical staff to reduce the internal risk. The major areas of concentration are procurement management, the competitive tendering process, and realistic cost estimation before tendering. Moreover, the external risk is also significant, such as unforeseen events, weather conditions, and labor strikes, which can influence risk of TC. The organizations in Pakistan can mitigate the external risk by formulating strict monitoring policies on clause provisions to discourage opportunistic contractors from undue extra claims.

There were few limitations of this study, which can open avenues for future research. First, this study has taken only the organization perspective. It can be improved by getting responses from private sector organizations in a similar industry. Second, this study is limited to a specific country; future research in different countries may help to provide further evidence in another context for the generalizability of the findings. Third, this study should also be undertaken in projects across diverse industries because different industries have many common characteristics [77], which may lead to finding the risk escalation factors and their influence on TC in a diverse project environment. 
Author Contributions: Z.A. and F.Z. conceived and designed the data. The analysis was conducted by Z.A. and S.H. Z.A. and S.H. with five group members collected the data from different regions of Pakistan and Z.A. wrote the manuscript.

Funding: This research was funded by National Natural Science Foundation of China under Grant No. 71372085.

Acknowledgments: This research work was supported by the National Natural Science Foundation of China under Grant No. 71372085. Furthermore, the worthy comments and suggestions from the editor and all the reviewers are extremely appreciated.

Conflicts of Interest: The authors declare no conflict of interest.

\section{References}

1. Jaafari, A. Management of risks, uncertainties and opportunities on projects: Time for a fundamental shift. Int. J. Proj. Manag. 2001, 19, 89-101. [CrossRef]

2. Williamson, O.E. The Economic Institutions of Capitalism. Firms, Markets, Relational Contracting; The Free Press: New York, NY, USA, 1985; ISBN 002934820X.

3. Whittington, J. When to partner for public infrastructure?: Transaction cost evaluation of design-build delivery. J. Am. Plan. Assoc. 2012, 78, 269-285. [CrossRef]

4. Arditi, D.; Pulket, T. Predicting the outcome of construction litigation using an integrated artificial intelligence model. J. Comput. Civ. Eng. 2009, 24, 73-80. [CrossRef]

5. Shane, J.S.; Molenaar, K.R.; Anderson, S.; Schexnayder, C. Construction Project Cost Escalation Factors. J. Manag. Eng. 2009, 25, 221-229. [CrossRef]

6. Gkritza, K.; Labi, S. Estimating Cost Discrepancies in Highway Contracts: Multistep Econometric Approach. J. Constr. Eng. Manag. 2008, 134, 953-962. [CrossRef]

7. Hallikas, J.; Virolainen, V.; Tuominen, M. Understanding risk and uncertainty in supplier networks-A transaction cost approach. Int. J. Prod. Res. 2010, 7543. [CrossRef]

8. Lu, W.; Zhang, L.; Pan, J. Identification and analyses of hidden transaction costs in project dispute resolutions. Int. J. Proj. Manag. 2015, 33, 711-718. [CrossRef]

9. KarimiAzari, A.; Mousavi, N.; Mousavi, S.F.; Hosseini, S. Risk assessment model selection in construction industry. Expert Syst. Appl. 2011, 38, 9105-9111. [CrossRef]

10. Jobin, D. A Transaction cost-based approach to partnerships perfromance evaluation. Evaluation 2008, 14, 437-465. [CrossRef]

11. Manu, E.; Ankrah, N.; Chinyio, E.; Proverbs, D. Trust influencing factors in main contractor and subcontractor relationships during projects. Int. J. Proj. Manag. 2015, 33, 1495-1508. [CrossRef]

12. Lee, H.; Seo, J.; Park, M.; Asce, M.; Ryu, H.; Kwon, S. Transaction-Cost-Based Selection of Appropriate General Contractor-Subcontractor Relationship Type. J. Constr. Eng. Manag. 2009, 135, 1232-1240. [CrossRef]

13. Soliño, A.S.; de Santos, P.G. Transaction costs in transport public-private partnerships: Comparing procurement procedures. Transp. Rev. 2010, 30, 389-406. [CrossRef]

14. Farajian, M. Transaction Cost Model for Infrastructure Public Private Partnerships in the US. Master's Thesis, University of Maryland, College Park, MD, USA, 2010.

15. Li, H.; Arditi, D.; Zang, Z. Factors that affect transaction costs in construction projects. J. Constr. Eng. Manag. 2013, 139, 60-68. [CrossRef]

16. Guo, L.; Li, H.; Li, P.; Zhang, C. Transaction costs in construction projects under uncertainty. Kybernetes 2016, 45, 866-883. [CrossRef]

17. Creedy, G.D.; Skitmore, M.; Wong, J.K.W. Evaluation of Risk Factors Leading to Cost Overrun in Delivery of Highway Construction Projects. J. Constr. Eng. Manag. 2011, 136, 528-537. [CrossRef]

18. El-Sayegh, S.M.; Mansour, M.H. Risk Assessment and Allocation in Highway Construction Projects in the UAE. J. Manag. Eng. 2015, 31, 04015004. [CrossRef]

19. El-Sayegh, S.M. Risk assessment and allocation in the UAE construction industry. Int. J. Proj. Manag. 2008, 26, 431-438. [CrossRef]

20. Chang, A.S.-T. Reasons for Cost and Schedule Increase for Engineering Design Projects. J. Manag. Eng. 2002. [CrossRef]

21. Li, H.; Arditi, D.; Wang, Z. Transaction costs incurred by construction owners. Eng. Constr. Archit. Manag. 2014, 21, 444-458. [CrossRef] 
22. Rasheli, G.A.; Rasheli, G.A. Procurement contract management in the local government authorities ( LGAs) in Tanzania A transaction cost approach. Int. J. Public Sect. Manag. 2016, 29, 545-564. [CrossRef]

23. Whittington, J.M. The transaction Cost Economics of Highway Project Delivery: Design-Build Contracting in Three States. Ph.D. Dissertation, University of California, Berkeley, CA, USA, 2008.

24. Hussain, S.; Fangwei, Z.; Siddiqi, A.F.; Ali, Z.; Shabbir, M.S. Structural Equation Model for Evaluating Factors Affecting Quality of Social Infrastructure Projects. Sustainability 2018, 10, 1415. [CrossRef]

25. Hair, J.F., Jr.; Hult, G.T.M.; Ringle, C.; Sarstedt, M. A Primer on Partial Least Squares Structural Equation Modeling (PLS-SEM); Sage Publications: Los Angeles, CA, USA, 2016; ISBN 978-1483377445.

26. Hussain, S.; Zhu, F.; Ali, Z.; Xu, X. Rural residents' perception of construction project delays in Pakistan. Sustainability 2017, 9, 2108. [CrossRef]

27. Mentis, M. Managing project risks and uncertainties. Mentis For. Ecosyst. 2015, 2. [CrossRef]

28. Brown, T.L.; Potoski, M. TRANSACTION COSTS and Conracting: The Practitioner Perspective. Public Perform. Manag. Rev. 2005, 28, 326-351. [CrossRef]

29. Sfakianaki, E.; Iliadis, T.; Zafeiris, E. Crisis management under an economic recession in construction: The Greek case. Int. J. Manag. Decis. Mak. 2015, 14, 373. [CrossRef]

30. Perminova, O.; Gustafsson, M.; Wikstrom, K. Defining uncertainty in projects-A new perspective. Int. J. Proj. Manag. 2008, 26, 73-79. [CrossRef]

31. Siemiatycki, M. Cost Overruns on Infrastructure Projects: Patterns, Causes, and Cures; Institute of Muncipal Finance \& Governance (IMFG): Toronto, ON, Canada, 2015.

32. Winch, G.; Leiringer, R. Owner project capabilities for infrastructure development: A review and development of the "strong owner" concept. Int. J. Proj. Manag. 2016, 34, 271-281. [CrossRef]

33. Ozorhon, B.; Arditi, D.; Dikmen, I.; Birgonul, M. Performance of International Joint Ventures in Construction. J. Manag. Eng. 2010, 26, 209-222. [CrossRef]

34. Silva, H. De Using ICT to reduce transaction costs in agriculture through better communication: A case study from Sri Lanka. LIRNEasia, Colombo Sri Lanka 2008. [CrossRef]

35. Li, H.; Arditi, D.; Wang, Z. Determinants of transaction costs in construction projects. J. Civ. Eng. Manag. 2015, 21, 548-558. [CrossRef]

36. Sambasivan, M.; Deepak, T.J.; Salim, A.N.; Ponniah, V. Analysis of delays in Tanzanian construction industry. Eng. Constr. Archit. Manag. 2017, 24, 308-325. [CrossRef]

37. Alaloul, W.S.; Liew, M.S.; Amila, N.; Abdullah, W. Identification of coordination factors affecting building projects performance. Alexandria Eng. J. 2016, 55, 2689-2698. [CrossRef]

38. OGP. Cost Control: Price Variation Clauses; Offiice of Government procurment (OGP), Department of Public expenditure and Reforms, Governmet of Dublin: Dublin, Ireland, 2016.

39. Chaturvedi, S.; Thakkar, J.J.; Shankar, R. Labor productivity in the construction industry: An evaluation framework for causal. Benchmarking Int. J. 2018, 25, 334-356. [CrossRef]

40. Semple, C.; Hartman, F.T.; Jergeas, G. Construction Claims and Disputes: Causes and Cost/Time Overruns. J. Constr. Eng. Manag. 1994, 120, 785-795. [CrossRef]

41. Krajangsri, T.; Pongpeng, J. Effect of Sustainable Infrastructure Assessments on Construction Project Success Using Structural Equation Modeling. J. Manag. Eng. 2016, 33, 4016056. [CrossRef]

42. Yean, F.; Ling, Y.; To, V.; Hoang, P. Political, Economic, and Legal Risks Faced in International Projects: Case Study of Vietnam. J. Prof. Issues Eng. Educ. Pract. 2010, 136, 156-164.

43. Cheung, S.O.; Pang, K.H.Y. Anatomy of Construction Disputes. J. Constr. Eng. Manag. 2013, 139, 15-23. [CrossRef]

44. Chang, T.; Deng, X.; Hwang, B.; Zhao, X. Political Risk Paths in International Construction Projects: Case Study from Chinese Construction Enterprises. Adv. Civ. Eng. 2018, 2018, 6939828. [CrossRef]

45. Adeleke, A.Q.; Bahaudin, A.Y.; Kamaruddeen, A.M.; Bamgbade, J.A.; Salimon, M.G.; Khan, M.W.A.; Sorooshian, S. The Influence of Organizational External Factors on Construction Risk Management among Nigerian Construction Companies. Saf. Health Work 2018, 9, 115-124. [CrossRef] [PubMed]

46. Ho, S.P.; Asce, A.M.; Levitt, R.; Asce, D.M.; Tsui, C.; Hsu, Y. Opportunism-focused transaction cost analysis of public-private partnerships. J. Manag. Eng. 2015, 31, 1-11. [CrossRef]

47. Dahlstrom, R.; Nygaard, A. Empirical Investigation of in Ex Post Transaction Costs Distribution Channels Franchised. J. Mark. Res. 1999, 36, 160-170. [CrossRef] 
48. Becker, J.; Klein, K.; Wetzels, M. Hierarchical Latent Variable Models in PLS-SEM: Guidelines for Using Reflective-Formative Type Models. Long Range Plan. 2012, 45, 359-394. [CrossRef]

49. Ali, F.; Rasoolimanesh, S.M.; Sarstedt, M.; Ringle, C.M.; Ryu, K. An assessment of the use of partial least squares structural equation modeling (PLS-SEM) in hospitality research. Int. J. Contemp. Hosp. Manag. 2018, 30, 514-538. [CrossRef]

50. Tech, I.; Social, B.; Survey, A.; Rabe-hesketh, S.; Skrondal, A.; Rabe-hesketh, S.; Hall, T. Generalized multilevel structural equation modeling. Psychometrika 2004, 69, 167-190.

51. Hair, J.F.; Black, W.C.; Babin, B.J.; Anderson, R.E.; Tatham, R.L. Multivariate Data Analysis; Prentice Hall: Upper Saddle River, NJ, USA, 2010.

52. Shah, S.; Ahmad, N.; Shen, Y.; Pirdavani, A.; Basheer, M.; Brijs, T. Road Safety Risk Assessment: An Analysis of Transport Policy and Management for Low-, Middle-, and High-Income Asian Countries. Sustainability 2018, 10, 389. [CrossRef]

53. Eybpoosh, M.; Dikmen, I.; Birgonul, M.T. Identification of risk paths in international construction projects using structural equation modeling. J. Constr. Eng. Manag. 2011, 137, 1164-1175. [CrossRef]

54. Fukunaga, K.; Huffman, W.E. The role of risk and transaction costs in contract design: Evidence from farmland lease contracts in U.S. agriculture. Am. J. Agric. Econ. 2009, 91, 237-249. [CrossRef]

55. Li, M.; Li, Q.; Deng, X. Transaction Cost Analysis of PPP Risk Share. In International Conference on Construction and Real Estate Management; QUT, Digital Repository: Toronto, ON, Canada, 2008; pp. 4-5.

56. Saunders, M.; Lewis, P.; Thornhill, A. Research Methods for Business Students, 7th ed.; Pearson Education Limited: London, UK, 2016.

57. Ye, G.; Jin, Z.; Xia, B.; Skitmore, M. Analyzing Causes for Reworks in Construction Projects in China. J. Manag. Eng. 2015, 31, 04014097. [CrossRef]

58. Günhan, S.; Arditi, D.; Doyle, J. Avoiding Change Orders in Public School Construction. J. Prof. Issues Eng. Educ. Pract. 2007, 133, 67-73. [CrossRef]

59. Assaf, S.; Hassanain, M.A.; Al-zahrani, S. Causes of Contractors' Failure in Industrial Projects in Saudi Arabia Causes of Contractors' Failure in Industrial Projects in Saudi Arabia. Res. J. Appl. Sci. Eng. Technol. 2015, 9, 158-164. [CrossRef]

60. Love, P.E.D.; Edwards, D.J.; Smith, J.; Walker, D.H.T. Divergence or Congruence? A Path Model of Rework for Building and Civil Engineering Projects. J. Perform. Constr. Facil. 2009, 23, 480-488. [CrossRef]

61. Babbie, E. The Practice of Social Research, 13th ed.; Wadsworth, Cengage Learning: Belmont, CA, USA, 2013.

62. Ullman, J.B.; Bentler, P.M. Structural Equation Modeling. In Handbook of Psychology, 2nd ed.; Weiner, I.B., Ed.; Wiley Online Library: New York, NY, USA, 2013.

63. Henseler, J.; Ringle, C.M.; Sinkovics, R.R. The use of partial least squares path modeling in international marketing. Adv. Int. Mark. 2009, 20, 277-319. [CrossRef]

64. Hair, J.F.; Sarstedt, M.; Ringle, C.M.; Mena, J.A. An assessment of the use of partial least squares structural equation modeling in marketing research. J. Acad. Mark. Sci. 2012, 40, 414-433. [CrossRef]

65. Ringle, C.M. PLS-SEM: Indeed a Silver Bullet. J. Mark. Theory Pract. 2011, 19, 139-152. [CrossRef]

66. Fornell, C.; Larcker, D.F. Evaluating structural equation models with unobservable variables and measurement error. J. Mark. Res. 1981, 18, 39-50. [CrossRef]

67. Henseler, J.; Ringle, C.M.; Sarstedt, M. A new criterion for assessing discriminant validity in variance-based structural equation modeling. J. Acad. Mark. Sci. 2015, 43, 115-135. [CrossRef]

68. Tenenhaus, M.; Vinzi, V.E.; Chatelin, Y.-M.; Lauro, C. PLS path modeling. Comput. Stat. Data Anal. 2005, 48, 159-205. [CrossRef]

69. Henseler, J.; Hubona, G.; Ray, P.A. Using PLS path modeling in new technology research: Updated guidelines. Ind. Manag. Data Syst. 2016, 116, 2-20. [CrossRef]

70. Barber, R.B. Understanding internally generated risks in projects. Int. J. Proj. Manag. 2005, 23, 584-590. [CrossRef]

71. Hughes, W.; Hillebrandt, P.; Greenwood, D.; Kwawu, W. Procurement in the Construction Industry: The Impact and Cost of Alternative Market and Supply Processes; Taylor \& Francis: London, UK; New York, NY, USA, 2006.

72. Kapelko, M.; Oude, A.; Stefanou, S.E. Assessing dynamic inefficiency of the Spanish construction sector preand post-financial crisis. Eur. J. Oper. Res. 2014, 237, 349-357. [CrossRef]

73. Ferris, J.M.; Graddy, E. Production Costs, Transactions Costs and Local Government Contractor Choice. Econ. Inq. 1989, 29, 541-554. [CrossRef] 
74. Laptali, E.; Erdis, E. Crisis management in Turkish construction industry. Build. Environ. 2006, 41, 1498-1503. [CrossRef]

75. Maqbool, R.; Sudong, Y. Critical success factors for renewable energy projects; empirical evidence from Pakistan. J. Clean. Prod. 2018, 195, 991-1002. [CrossRef]

76. Brown, T.L.; Potoski, M. Managing Contract Performance: A Transaction Costs Approach. J. Policy Anal. Manag. 2003, 22, 275-297. [CrossRef]

77. Chou, J.; Pramudawardhani, D. Cross-country comparisons of key drivers, critical success factors and risk allocation for public-private partnership projects. Int. J. Project Manag. 2015, 33, 1136-1150. [CrossRef]

(C) 2018 by the authors. Licensee MDPI, Basel, Switzerland. This article is an open access article distributed under the terms and conditions of the Creative Commons Attribution (CC BY) license (http:/ / creativecommons.org/licenses/by/4.0/). 